\title{
Improved viability of bifidobacteria in fermented milk by cocultivation with Lactococcus lactis subspecies lactis
}

\author{
T. Odamaki, ${ }^{1}$ J. Z. Xiao, S. Yonezawa, T. Yaeshima, and K. Iwatsuki \\ Food Science and Technology Institute, Morinaga Milk Industry Co. Ltd., Zama, Kanagawa 228-8583, Japan
}

\begin{abstract}
The poor survival of probiotic bacteria in commercial yogurts may limit their potential to exert health benefits in humans. The objective was to improve the survival of bifidobacteria in fermented milk. Cocultivation with some strains of Lactococcus lactis ssp. lactis improved the survival of bifidobacteria in fermented milk during refrigerated storage. Studies on one strain, Lc. lactis ssp. lactis MCC866, showed that the concentrations of dissolved oxygen were kept lower in the cocultivated fermented milk during storage compared with monocultured Bifidobacterium longum BB536 or samples cocultured with another noneffective Lc. lactis ssp. lactis strain. Degradation of genomic DNA was suppressed in the cocultivating system with Lc. lactis ssp. lactis MCC866. Several genes that participated in protection from active oxygen species (e.g., genes coding for alkyl hydroperoxide reductase and $\mathrm{Fe}^{2+}$ transport system) were expressed at higher levels during refrigerated storage in Lc. lactis ssp. lactis MCC 866 compared with another noneffective Lc. lactis ssp. lactis strain. Concentration of free iron ion was also lower in supernatants of fermented milk cocultivated with $B$. longum BB536 and Lc. lactis ssp. lactis MCC866. These results suggest that Lc. lactis ssp. lactis MCC 866 is potentially superior in reducing oxygen damage and consequently improves the survival of bifidobacteria in the cocultivating system. This cocultivation system is of industrial interest for producing fermented milk containing viable bifidobacteria with long shelf life.
\end{abstract}

Key words: Bifidobacterium, Lactococcus lactis, survival in fermented milk, dissolved oxygen

\section{INTRODUCTION}

Probiotic bacteria are living microorganisms that, when administered in adequate amounts, confer health benefits on the host (FAO/WHO, 2002). An increasing number of probiotic products is appearing in response

Received March 24, 2010.

Accepted November 15, 2010.

${ }^{1}$ Corresponding author: t-odamak@morinagamilk.co.jp to current health trends. In general, high numbers of viable probiotic bacteria are desired in these products at the moment of consumption. Typically, between 5 and $8 \mathrm{log} \mathrm{cfu} / \mathrm{g}$ of product is considered acceptable (Maragkoudakis et al., 2006). A recent meta-analysis has suggested that levels of lactobacilli of 7 to $9 \log \mathrm{cfu} / \mathrm{g}$ may be necessary to elicit antidiarrheal effects (Van Niel et al., 2002). Current proposals within the European Union set the minimum level of probiotic bacteria in foods at $7 \mathrm{log} \mathrm{cfu} / \mathrm{g}$ (EU/AGRI/38743/2003rev3).

Bifidobacteria are the major components of the intestinal microbiota of humans and animals and have attracted much attention because of their perceived contribution to health-promoting effects such as the improvement of gastrointestinal disorders and alleviation of allergy symptoms (Leahy et al., 2005; Picard et al., 2005; Turroni et al., 2009). For this reason, interest in creating food products containing these bacteria has been rapidly expanding, particularly in areas such as fermented milk and supplements. However, bifidobacteria are unable to generate sufficient acids for the manufacture of fermented foods with the appropriate aroma and flavor. They are, therefore, normally incorporated as live cultures into fermented dairy products that can serve as carrier foods, such as yogurt, by cofermentation with ordinary yogurt starters (Samona and Robinson, 1994). However, because bifidobacteria are often exposed to multiple environmental stressors such as low $\mathrm{pH}$, low temperature, high osmotic pressure, nutrient starvation, and oxidation, their cell numbers and survival in yogurt are limited. Attempts to coculture bifidobacterial strains with Lactobacillus delbrueckii ssp. bulgaricus $\mathrm{H}^{+}$-ATPase defective mutants (Ongol et al., 2007) or Streptococcus thermophilus with or without other strains such as Lactobacillus acidophilus (Mollet, 1999) have enhanced the survival of bifidobacteria in fermented milk. Microencapsulation of bifidobacteria also increases their survival in yogurt (Adhikari et al., 2000).

We have previously reported that cocultivation with Lactococcus lactis ssp. lactis harboring cell wallanchored proteinase (PrtP) stimulates the growth of bifidobacteria in fermented milk (Yonezawa et al., 2010). Oligopeptides and amino acids released from 
milk proteins by Lc. lactis PrtP help stimulate bifidobacterial growth during cocultivation. We also found that cocultivation with some strains of Lc. lactis ssp. lactis markedly improve the survival of bifidobacteria in fermented milk during refrigerated storage. In this report, we present results on the improved survival of bifidobacteria in fermented milk by cocultivation with Lc. lactis ssp. lactis together with some mechanistic data.

\section{MATERIALS AND METHODS}

\section{Bacterial Strains}

Type strains of bifidobacteria were purchased from the Japan Collection of Microorganisms (Riken Bioresource Center, Wako, Japan). Bifidobacterium longum ssp. longum BB536 (ATCC BAA-999) is a probiotic strain from the Morinaga Culture Collection (MCC; Morinaga Milk Industry, Zama, Japan), which was originally isolated from feces of a healthy infant. Lactococcus lactis ssp. lactis strains that originated from dairy products were obtained from MCC. Both Lc. lactis ssp. lactis strains MCC857 and MCC866 harbor PrtP and stimulate the growth of bifidobacteria in fermented milk (Yonezawa et al., 2010).

\section{Preparation of Fermented Milk}

Seed cultures of the Lc. lactis ssp. lactis strains were grown at $30^{\circ} \mathrm{C}$ for $6 \mathrm{~h}$ in $10 \%$ (wt/wt) reconstituted skim milk (Morinaga Milk Industry) containing 0.3\% (wt/wt) yeast extract (Becton Dickinson, Franklin Lakes, NJ). Seed cultures of bifidobacteria (Table 1) were prepared by growth in de Man, Rogosa, and Sharpe broth (Becton Dickinson) for $16 \mathrm{~h}$ at $37^{\circ} \mathrm{C}$ in glass test tubes. Cells were collected by centrifugation and then resuspended in sterile saline composed of $0.85 \% \mathrm{NaCl}$ to a concentration of approximately $5 \times$ $10^{8} \mathrm{cfu} / \mathrm{mL}$. The seed culture of B. longum BB536 was prepared by culturing at $37^{\circ} \mathrm{C}$ for $4 \mathrm{~h}$ in $11 \%$ (wt/wt) reconstituted skim milk containing $0.2 \%$ (wt/wt) yeast extract in glass test tubes. For preparation of fermented milk by a monoculture of bifidodobacteria, a $1 \%$ inoculum of seed culture was added to $10 \%$ skim milk medium supplemented with an optimal concentration of yeast extract, as shown in Table 1, and incubated in glass bottles at $37^{\circ} \mathrm{C}$ until reaching $\mathrm{pH}$ 4.6. Some strains were not able to reach $\mathrm{pH} 4.6$ after incubation for $16 \mathrm{~h}$, even with higher concentrations of yeast extract. For preparation of fermented milk containing bifidobacteria cocultivated with Lc. lactis ssp. lactis, $10 \%$ skim milk medium was inoculated with each bifi- dobacteria seed culture and $1 \%$ of a seed culture of $L c$. lactis ssp. lactis and incubated at $37^{\circ} \mathrm{C}$ until the $\mathrm{pH}$ reached the same as that produced by monocultivation of each bifidobacteria strain in glass bottles. Fermented milk $(5 \mathrm{~mL})$ was dispersed into polyethylene centrifuge tubes (Eiken Kizai, Tokyo, Japan) that had an oxygen transmission rate of approximately $0.15 \mathrm{~mL} / \mathrm{d}$ atm at $25^{\circ} \mathrm{C}$, and stored at $10^{\circ} \mathrm{C}$ until analysis. To check the effect of hydrogen peroxide $\left(\mathrm{H}_{2} \mathrm{O}_{2}\right)$ on the viability of bifidobacteria, catalase (Wako Pure Chemical Industry, Osaka, Japan) was supplemented in the B. longum BB536 monoculture medium as described previously (Shimamura et al., 1992).

\section{Measurement of Bacterial Cell Number and Concentrations of Dissolved Oxygen, $\mathrm{H}_{2} \mathrm{O}_{2}$ and Free Iron}

Viable bacteria during storage were enumerated by plating appropriate dilutions on TOS propionate agar (Eiken) at $37^{\circ} \mathrm{C}$ for $48 \mathrm{~h}$ in anaerobic condition and on $\mathrm{BCP}$ agar (Eiken) at $30^{\circ} \mathrm{C}$ for $48 \mathrm{~h}$ in aerobic condition for bifidobacteria and Lc. lactis ssp. lactis, respectively (Lee and Lee, 2008; Yonezawa et al., 2010). Dissolved oxygen (DO) was measured using a model FO-960S fluorescence oxygen sensor (ASR, Tokyo, Japan). Samples were kept in a cooler bath at $10^{\circ} \mathrm{C}$ during measurement. $\mathrm{H}_{2} \mathrm{O}_{2}$ concentrations in the supernatant (centrifuged at $5,000 \times g$ for $10 \mathrm{~min}$ ) of fermented milk were determined using the Bioxytech $\mathrm{H}_{2} \mathrm{O}_{2}-560$ system (Oxis International, Beverley Hills, CA). The test is based on ferrous ion oxidation in the Fenton reaction $\left(\mathrm{Fe}^{2+}+\mathrm{H}_{2} \mathrm{O}_{2} \rightarrow \mathrm{Fe}^{3+}+{ }^{\cdot} \mathrm{OH}+\mathrm{OH}^{-}\right)$. Ferric iron is generated in the presence of $\mathrm{H}_{2} \mathrm{O}_{2}$, which forms a complex with xylenol orange that absorbs at $560 \mathrm{~nm} ; \mathrm{H}_{2} \mathrm{O}_{2}$ was quantified against known amounts of $\mathrm{H}_{2} \mathrm{O}_{2}$ standards. To measure free iron concentration in fermented milk, $20 \mu \mathrm{L}$ of each sample was injected and directly analyzed by inductively coupled plasma mass spectrometry (Agilent 7500ce; Agilent Technologies, Santa Clara, CA) as previously reported (Yamada et al., 2006). All assays were performed in triplicate.

\section{Monitoring of DNA Degradation}

One main target of oxygen induced cellular damage is DNA (Imlay et al., 1988; Duwat et al., 1995). To examine DNA integrity, chromosomal DNA was extracted from fermented milk. To $10 \mathrm{~mL}$ of fermented milk, an equal volume of $2 \%$ (wt/vol) trisodium citrate was added and then centrifuged at $500 \times g$ for $5 \mathrm{~min}$ to remove the curd. The supernatants were centrifuged at $5,000 \times g$ for 5 min to collect pellets (bacteria). Two 
milligrams of lysozyme, $1 \mu \mathrm{g}$ of $\mathrm{N}$-acetyl muramidase, and $0.1 \mathrm{mg}$ of RNase A were added to the pellets and incubated at $37^{\circ} \mathrm{C}$ for $16 \mathrm{~h}$, followed by further digestion with $0.5 \mathrm{mg}$ of protease $\mathrm{K}$. The digests were analyzed by electrophoreses with $0.8 \%$ Tris-borate EDTA agarose.

\section{Real-Time PCR}

Bacteria were collected from fermented milk as described above. Extraction and reverse transcription of RNA were performed using a RNeasy kit (Qiagen, Valencia, CA) and transcriptase (Applied Biosystems, Foster City, CA), respectively. The RNA levels of genes related to active oxygen species protection (Condon, 1987; Shimamura et al., 1992; Miyoshi et al., 2003) were determined by real-time PCR using an ABI Prism 7500 Fast Real Time PCR system (Applied Biosystems). All primer pairs were designed from genome sequences of Lc. lactis IL1403 and B. longum NCC2705 (http:// www.ncbi.nlm.nih.gov) by Primer3 (http://primer3. sourceforge.net/; Supplementary Table 1, available online: http://www.journalofdairyscience.org/). The amplification program consisted of $94^{\circ} \mathrm{C}$ for $10 \mathrm{~s}$, followed by 40 cycles of $94^{\circ} \mathrm{C}$ for $5 \mathrm{~s}$ and $60^{\circ} \mathrm{C}$ for $30 \mathrm{~s}$. Each PCR product was sequenced by using an ABI 3100-Avant apparatus (Applied Biosystems) and the sequences were analyzed by a BLAST search (http:// blast.ncbi.nlm.nih.gov/Blast.cgi). The PCR products were judged to have been amplified precisely if the BLAST search produced the top hits with the targeted genes. Melting curves were obtained by heating from $60^{\circ} \mathrm{C}$ to $95^{\circ} \mathrm{C}$ in increments of $0.2^{\circ} \mathrm{C} / \mathrm{s}$, with continuous fluorescence collection. All values indicated averages of relative expression levels of each gene at different time points against those after $8 \mathrm{~h}$ of fermentation with $L c$. lactis MCC857 in fermented milk cocultivated with $B$. longum BB536 for Lc. lactis or against those after $8 \mathrm{~h}$ of B. longum BB536 monoculture for bifidobacteria (mean $\pm \mathrm{SD}$, triplicate assays)

\section{Statistical Analyses}

All data were acquired in triplicate assays and are expressed as mean $\pm \mathrm{SD}$. Intergroup differences in the survival rate of bifidobacterial strains during refrigerated storage and those in gene expressions of Lc. lactis ssp. lactis were analyzed using the Student's t-test. Intergroup differences in gene expressions of $B$. longum BB536 and iron concentration were analyzed using the non-repeated-measures ANOVA with Bonferroni correction, respectively. Values of $P<0.05$ were considered statistically significant.

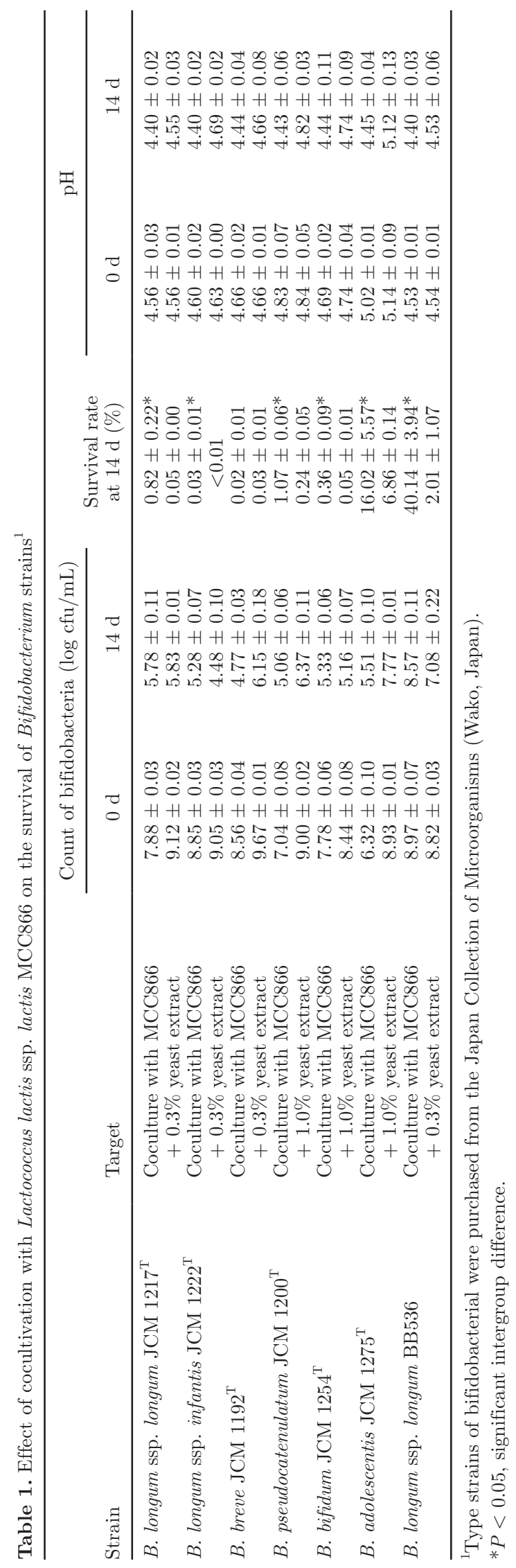




\section{RESULTS}

\section{Effect of Cocultivation with Lc. lactis ssp. lactis on the Survival of Bifidobacteria}

Some strains of Lc. lactis ssp. lactis stimulate the growth of bifidobacteria (Yonezawa et al., 2010) and others also improve the survival of bifidobacteria during refrigerated storage (our unpublished data). Lactococcus lactis ssp. lactis MCC866, which efficiently improved the growth and survival of B. longum BB536 (Table 1), was used to test the effect on the survival of different species of bifidobacteria in a cocultivation system. Type strains of Bifidobacterium pseudocatenulatum and Bifidobacterium adolescentis barely grew in the skim milk medium when cocultivated with Lc. lactis ssp. lactis MCC866. Furthermore, although the $\mathrm{pH}$ after fermentation for each strain during monocultivation or cocultivation was adjusted to the same levels, dissociation was observed after $14 \mathrm{~d}$ of storage for almost all strains. However, although it was strain-dependent, the survival rates after $14 \mathrm{~d}$ of storage in cocultivation were significantly higher compared with monoculture, with the exception of Bifidobacterium breve JCM $1192^{\mathrm{T}}$ (Table 1).

\section{Changes of $\mathrm{pH}$, Survival of Bacteria, and Concentrations of $\mathrm{DO}$ and $\mathrm{H}_{2} \mathrm{O}_{2}$ in Fermented Milk Containing $B$. longum BB536 During Refrigerated Storage}

Viable bacterial numbers of monocultivated $B$. longum BB536 decreased by approximately 2 logs at $14 \mathrm{~d}$, decreased by a further $2 \operatorname{logs}$ during the next $7 \mathrm{~d}$, and exhibited approximately 5 log-fold lower numbers after $4 \mathrm{wk}$ of storage compared with those after fermentation (Figure 1A). A similar temporal decrease of bifidobacteria was observed during cocultivation with Lc. lactis ssp. lactis MCC857 (Figure 1A). However, the survival rates were markedly improved by cocultivation with Lc. lactis ssp. lactis MCC866; viable bacterial numbers of B. longum BB536 were maintained until 21 $\mathrm{d}$ and were maintained at over 2 logs higher than those of monocultivated bacteria after $4 \mathrm{wk}$ of storage (Figure 1A). Survival of Lc. lactis ssp. lactis MCC857 and MCC866 was stable until $21 \mathrm{~d}$, without marked difference between monocultivation and cocultivation with B. longum BB536 (Figure 1B). The $\mathrm{pH}$ for fermented milk containing Lc. lactis ssp. lactis decreased about 0.2 in the first week for both monocultivation and cocultivation with $B$. longum BB536, and maintained at a steady level in the later stages of storage (Figure 1C). No marked change of $\mathrm{pH}$ was found for the samples of monocultivated $B$. longum BB536 during storage
(Figure 1C). Concentrations of DO in fermented milk containing bifidobacteria monocultivated or cocultivated with $L$ c. lactis ssp. lactis MCC857 started increasing from $7 \mathrm{~d}$ and leveled to $6 \mathrm{ppm}$ or higher at 14 d during storage. However, the DO concentrations were low in the fermented milk cocultivated with Lc. lactis ssp. lactis MCC866 until $14 \mathrm{~d}$ and were maintained at the lower levels compared with monocultivation or cocultivation with Lc. lactis ssp. lactis MCC857 at $21 \mathrm{~d}$ (Figure 1D). The DO levels in samples with $L c$. lactis ssp. lactis MCC866 were lower compared with those with MCC857 in monocultivation during storage (Figure 1D). The concentrations of $\mathrm{H}_{2} \mathrm{O}_{2}$, an intermediary metabolite of scavenged oxygen, were maintained at lower levels in fermented milk except for those of cocultivation of B. longum BB536 and Lc. lactis ssp. lactis MCC866, in which the concentrations were higher after fermentation compared with the other samples, increased further at $7 \mathrm{~d}$ and $14 \mathrm{~d}$, and then, along with the increased concentrations of DO, decreased at 21 and $28 \mathrm{~d}$ to levels similar to those of the other samples (Figure 1E). Furthermore, supplementation of catalase to $B$. longum BB536 monoculture did not affect the viability of $B$. longum $\mathrm{BB} 536$ or the concentrations of DO, although $\mathrm{H}_{2} \mathrm{O}_{2}$ was lowered during storage (Figures $1 \mathrm{~A}, \mathrm{D}$, and $\mathrm{E}$ ).

\section{DNA Degradation During Refrigerated Storage}

Because the electrophoresis patterns obtained from samples at 7 and $14 \mathrm{~d}$ were similar to that at $0 \mathrm{~d}$ (data not shown), DNA was predicted to be stable until 14 d. However, degradations were observed in fermented milk containing B. longum BB536 in monoculture or in coculture with Lc. lactis ssp. lactis MCC857 after $21 \mathrm{~d}$ of storage, but no marked degradation was found for those cocultured with Lc. lactis ssp. lactis MCC866, even after $28 \mathrm{~d}$ of storage (Figure 2).

\section{Gene Expressions of Bacteria in Fermented Milk}

Table 2 shows the relative expression levels of major genes that participated in oxygen utilization and protection from active oxygen species examined by reverse transcription-quantitative PCR. For Lc. lactis ssp. lactis, the genes noxC, noxD, noxE, poxL, glpD, $a h p C$, and $f e o B$ were expressed at the highest levels after fermentation compared with during the refrigerated stage (Table 2). Significantly higher expression levels during fermentation were found for all genes except noxD, ahpF, and $f e o B$ in Lc. lactis ssp. lactis MCC857 compared with Lc. lactis ssp. lactis MCC 866. Notably, some genes were expressed at higher levels during storage for 7 and $14 \mathrm{~d}$ in Lc. lactis ssp. lactis 

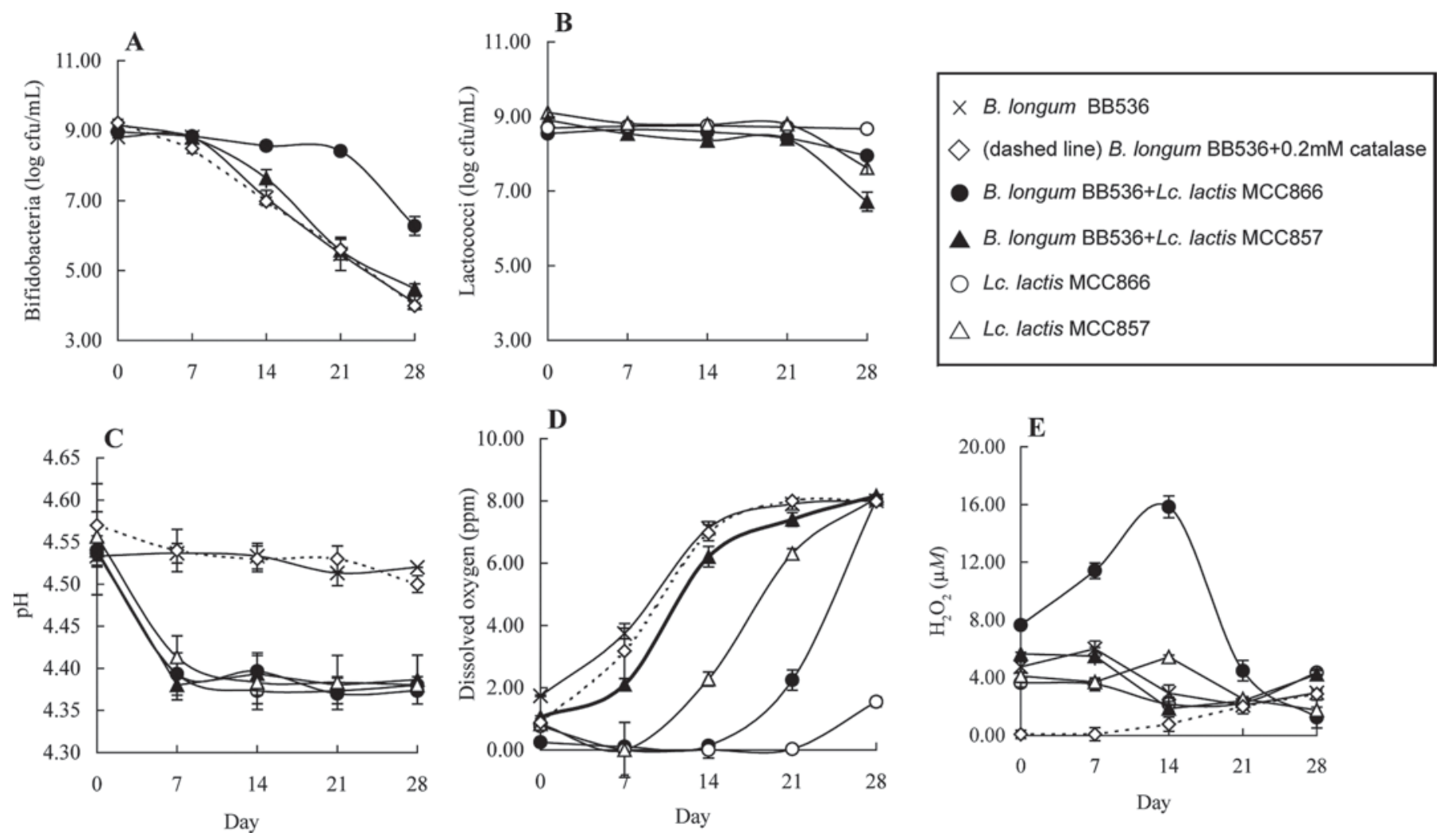

Figure 1. Changes of survival of bifidobacteria and circumferential conditions in fermented milk during refrigerated storage. A) Cell numbers of Bifidobacterium (cfu/mL); B) cell numbers of Lactococcus lactis (cfu/mL); C) pH; D) dissolved oxygen (ppm); E) $\mathrm{H}_{2} \mathrm{O}_{2}$ concentration ( $\mu M$ ). Experiments were performed 4 times with comparable results. Results of representative experiments are shown; all data represent triplicate assays.

MCC866 compared with Lc. lactis ssp. lactis MCC857: 2 examples are alkyl hydroperoxide reductase $(a h p C$ : 2.26-fold, $a h p F$ : 5.86-fold), which form 2-component enzymes to convert $\mathrm{H}_{2} \mathrm{O}_{2}$ to $\mathrm{H}_{2} \mathrm{O}$; and $\mathrm{Fe}^{2+}$ transport system ( $f e o B, 11.31$-fold at $7 \mathrm{~d}$ and 14.69-fold at 14 d). In contrast to results for Lc. lactis ssp. lactis, the expression levels of genes encoding alkyl hydroperoxide reductase and $\mathrm{H}_{2} \mathrm{O}$-forming $\mathrm{NADH}$ oxidase were lower after fermentation $(0 \mathrm{~d})$ than during the exponential phase in B. longum BB536 (Table 3). Furthermore, the expression levels of these genes were enhanced markedly during refrigerated storage (Table 3 ). Notably, the expression level of $a h p C$ was more than 500-fold higher in B. longum BB536 monocultivation at $14 \mathrm{~d}$ of storage compared with those after fermentation, which was significantly higher compared with those cocultivated with Lc. lactis ssp. lactis. The expression levels of $a h p C$ were significantly lower during fermentation or storage when cocultivated with Lc. lactis ssp. lactis MCC866 compared with those with Lc. lactis ssp. lactis MCC857 (0 d: 0.19-fold; 7 d: 0.24-fold, and 14 d: 0.63-fold).

\section{Free Iron Concentration in Fermented Milk Containing B. longum BB536}

The free iron level was significantly lower in fermented milk cocultivated with Lc. lactis ssp. lactis MCC866 $(57.2 \pm 14.1 \mathrm{ng} / \mathrm{g})$ at $0 \mathrm{~d}$ compared with monocultivation $(93.9 \pm 11.7 \mathrm{ng} / \mathrm{g})$ or cocultivation with Lc. lactis ssp. lactis MCC857 (93.7 $\pm 11.3 \mathrm{ng} / \mathrm{g})$.

\section{DISCUSSION}

During refrigerated storage of fermented milk, microorganisms are often exposed to multiple environmental stresses such as low $\mathrm{pH}$, low temperature, high osmotic pressure, nutrient starvation, and oxidation, which lead to the loss of viability. However, among the reasons responsible for the loss of survival of bifidobacteria in fermented milk, low $\mathrm{pH}$ and oxidation are considered the most important factors (Shah and Jellen, 1990; Talwalkar and Kailasapathy, 2003; Jayamanne and Adams, 2006). 


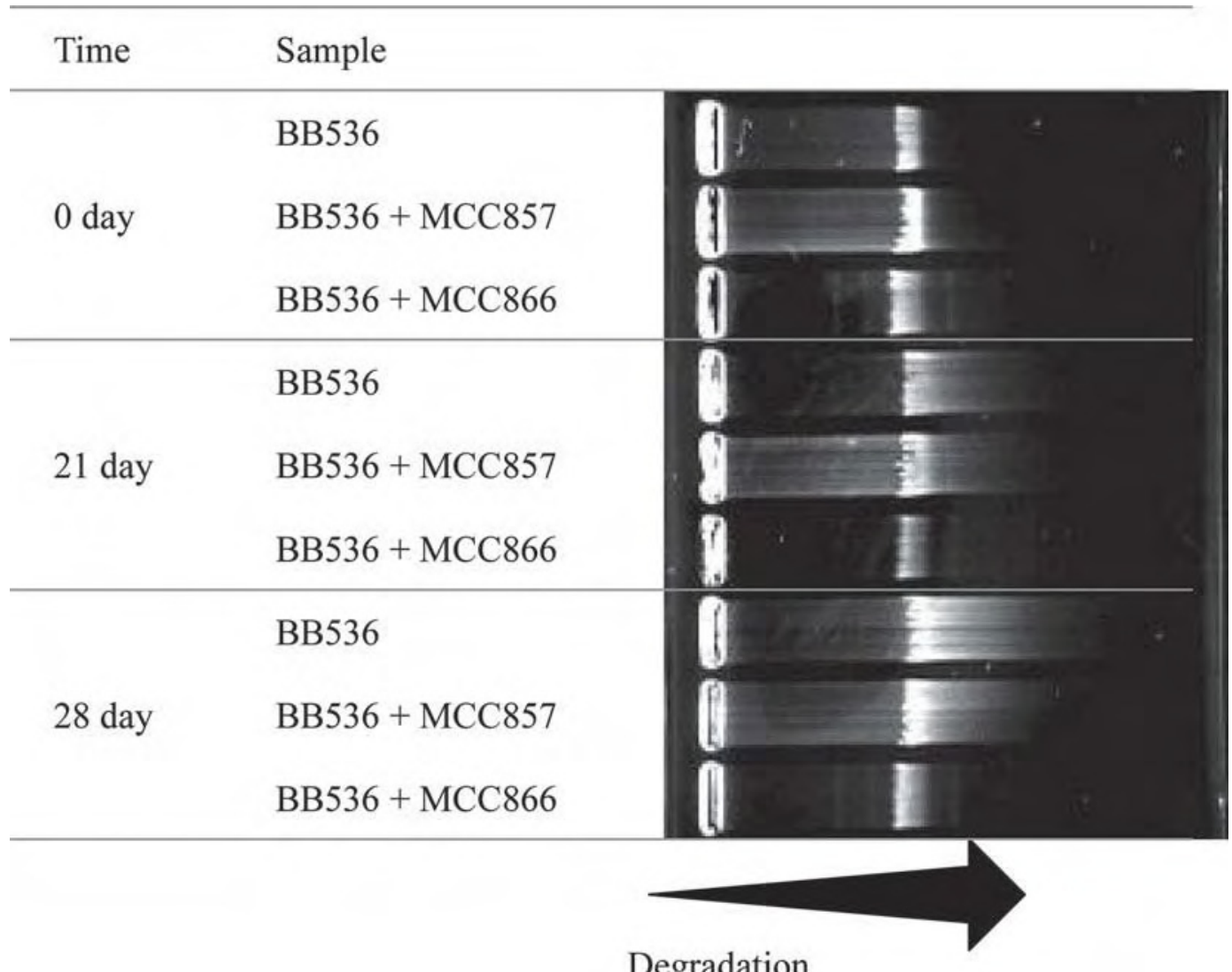

Figure 2. Degradation of DNA in fermented milk during refrigerated storage. A gel representative of 3 experiments is shown. BB536 $=$ Bifidobacterium longum; MCC857 = Lactococcus lactis MCC857; MCC866 = Lactococcus lactis MCC866.

Attempts to provide a mildly acidic environment by stopping fermentation at a higher $\mathrm{pH}$ (Gilliland et al., 2002 ) or cocultivating bifidobacterial strains with $L b$. delbrueckii ssp. bulgaricus $\mathrm{H}^{+}$-ATPase defective mutants (Ongol et al., 2007) enhanced the survival of bifidobacteria in fermented milk. In the present study, the concentration of DO was kept at a low level in fermented milk cocultivated with Lc. lactis ssp. lactis MCC866 during storage, even though the $\mathrm{pH}$ was slightly lowered compared with BB536 monocultivation. These results suggest that the level of DO, rather than the moderate postacidification, affected the survival of $B$. longum BB536 during storage, and Lc. lactis ssp. lactis strain MCC866 improved the survival of bifidobacteria during refrigerated storage, probably by protecting cells from oxidative stress. We also observed survival improvement of other bifidobacteria in cocultivation with Lc. lactis ssp. lactis MCC866. This was likely due to the difference in ability to grow in skim milk medium by each bifidobacterial strain: B. longum BB536 grew well in skim milk medium and so might derive a great benefit from Lc. lactis ssp. lactis MCC866.
Environmental oxygen is generally scavenged to $\mathrm{H}_{2} \mathrm{O}$ via $\mathrm{H}_{2} \mathrm{O}_{2}$ in an organism without a respiratory chain. However, $\mathrm{H}_{2} \mathrm{O}_{2}$ is one of the major reactive oxygen species and eventually inhibits bacterial growth (MartyTeysset et al., 2000; van de Guchte et al., 2001). To protect from oxidative damage, $\mathrm{H}_{2} \mathrm{O}_{2}$ is sequentially degraded by enzymes such as catalase or peroxidase in some microorganisms. Contrary to our expectation, the concentration of $\mathrm{H}_{2} \mathrm{O}_{2}$ was higher in the fermented milk containing bifidobacteria when cocultivated with the Lc. lactis ssp. lactis MCC866 at $14 \mathrm{~d}$ of storage compared with those of monocultivation. Furthermore, $\mathrm{H}_{2} \mathrm{O}_{2}$ levels subsequently decreased along with increased levels of DO after $21 \mathrm{~d}$ of storage in the cocultivating system containing bifidobacteria and Lc. lactis ssp. lactis MCC866. These results suggest that the fate of environmental oxygen was conversion to $\mathrm{H}_{2} \mathrm{O}_{2}$. Because accumulation of $\mathrm{H}_{2} \mathrm{O}_{2}$ only occurred in the cocultivating system but not in fermented milk monocultivated with Lc. lactis ssp. lactis MCC866, it can be suggested that the imbalance of $\mathrm{H}_{2} \mathrm{O}_{2}$ and $\mathrm{H}_{2} \mathrm{O}$ was caused by the coexistence of B. longum BB536 and Lc. lactis ssp. 
Table 2. Gene expression of Lactococcus lactis MCC857 and MCC866 during an 8-h fermentation and refrigerated storage in fermented milk cocultivated with bifidobacteria ${ }^{1}$

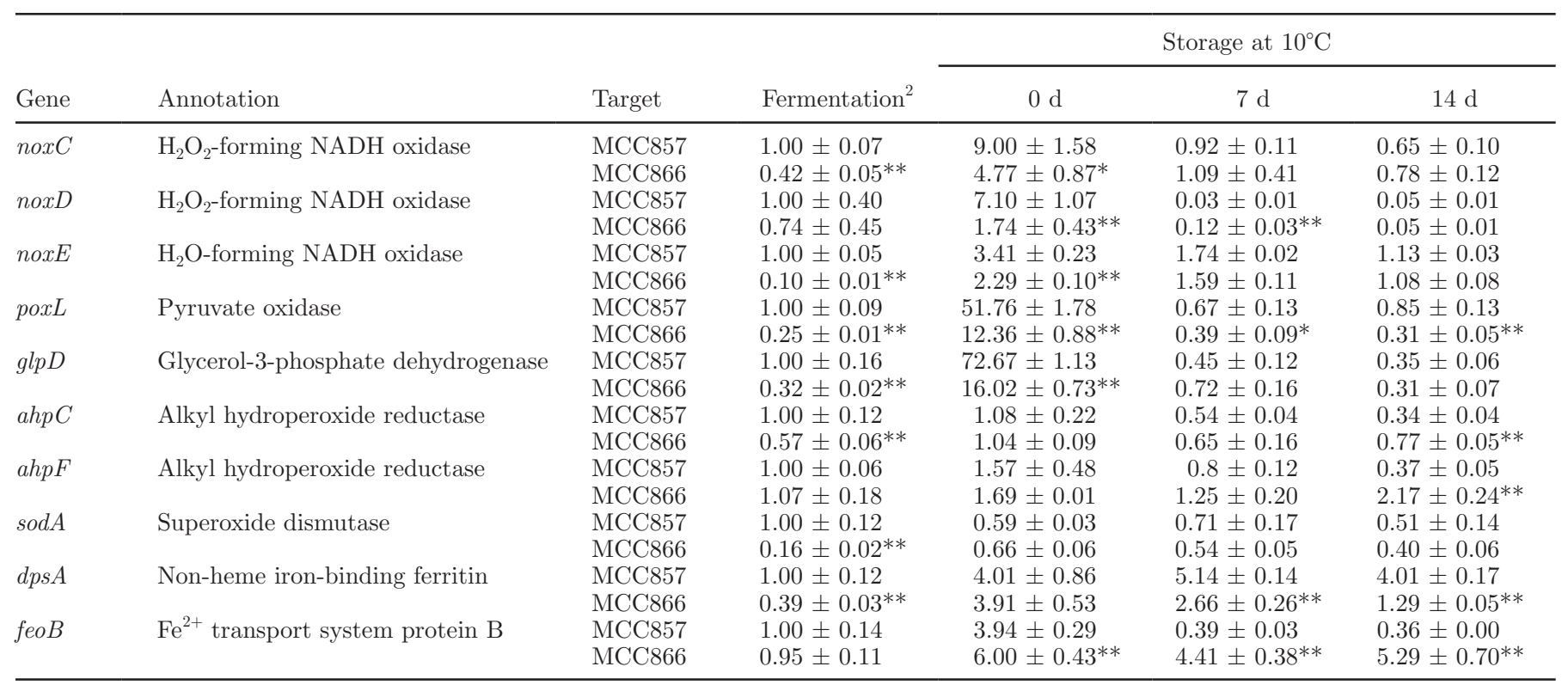

${ }^{1}$ All values indicate averages of relative expression levels of each gene at different time points against those at 8 h of Lactococcus lactis MCC857 in fermented milk cocultivated with Bifidobacterium. longum BB536 (mean $\pm \mathrm{SD}$, triplicate assays).

${ }^{2}$ Skim milk was fermented for $16 \mathrm{~h}$ until reaching $\mathrm{pH}$ approximately 4.6. The 8-h fermentation corresponds to an exponential phase with $\mathrm{pH}$ approximately 5.0.

${ }^{*} P<0.05,{ }^{* *} P<0.01$ : significant intergroup difference between Lc. lactis ssp. lactis MCC857 and Lc. lactis ssp. lactis MCC866 at each time point.

lactis MCC866. The mechanism is uncertain; however, one possibility is that the activity of $\mathrm{H}_{2} \mathrm{O}_{2}$ reducer such as alkyl hydroperoxide reductase of Lc. lactis ssp. lactis MCC866 was suppressed in the presence of B. longum BB536, without affecting the activity of NADH oxidase. The activity of NADH peroxidase is generally one-tenth to one-thirtieth of that of NADH oxidase (Miyoshi et al., 2003); therefore, it is expected that even a minor change in the activity of NADH peroxidase might affect the fate of $\mathrm{H}_{2} \mathrm{O}_{2}$ in fermented milk. A several-millimolar lethal dose of for $\mathrm{H}_{2} \mathrm{O}_{2}$ is thought to be needed to affect the bacterial growth dose (Duwat et al., 1995, 1999). However, the concentrations in the cocultivating system of bifidobacteria and Lc. lactis ssp. lactis MCC866 during storage were dozens of orders of magnitude lower compared with the suggested lethal dose. Doleyres et

Table 3. Gene expression of Bifidobacterium longum BB536 in fermented milk with or without Lactococcus lactis MCC857 or MCC866 during 8-h fermentation and storage ${ }^{1}$

\begin{tabular}{|c|c|c|c|c|c|c|}
\hline Gene & Annotation & Target & Fermentation $^{2}$ & \multicolumn{3}{|c|}{ Storage at $10^{\circ} \mathrm{C}$} \\
\hline $\operatorname{ahpC}$ & $\begin{array}{l}\text { Alkyl hydroperoxide } \\
\text { reductase }\end{array}$ & $\begin{array}{l}\text { BB } 536 \\
\quad+\text { MCC } 857 \\
\quad+\text { MCC } 866\end{array}$ & $\begin{array}{l}1.00 \pm 0.17^{\mathrm{a}} \\
0.20 \pm 0.02^{\mathrm{b}} \\
0.28 \pm 0.07^{\mathrm{b}}\end{array}$ & $\begin{array}{l}1.76 \pm 0.37^{\mathrm{a}} \\
0.95 \pm 0.14^{\mathrm{a}} \\
0.18 \pm 0.05^{\mathrm{b}}\end{array}$ & $\begin{array}{r}76.24 \pm 29.9^{\mathrm{a}} \\
35.71 \pm 1.13^{\mathrm{a}} \\
8.52 \pm 0.92^{\mathrm{b}}\end{array}$ & $\begin{aligned} 501.15 & \pm 101.46^{\mathrm{a}} \\
61.66 & \pm 3.75^{\mathrm{b}} \\
38.51 & \pm 1.29^{\mathrm{c}}\end{aligned}$ \\
\hline$a h p F$ & $\begin{array}{l}\text { Alkyl hydroperoxide } \\
\text { reductase }\end{array}$ & $\begin{array}{l}\text { BB536 } \\
\quad+\mathrm{MCC} 857 \\
+\mathrm{MCC} 866\end{array}$ & $\begin{array}{l}1.00 \pm 0.60^{\mathrm{a}} \\
3.58 \pm 0.50^{\mathrm{b}} \\
1.51 \pm 0.23^{\mathrm{a}}\end{array}$ & $\begin{array}{l}0.48 \pm 0.14^{\mathrm{a}} \\
0.22 \pm 0.04^{\mathrm{a}} \\
1.81 \pm 0.19^{\mathrm{b}}\end{array}$ & $\begin{aligned} 1.94 & \pm 0.18^{\mathrm{a}} \\
11.22 & \pm 0.81^{\mathrm{b}} \\
5.48 & \pm 1.02^{\mathrm{c}}\end{aligned}$ & $\begin{array}{l}11.3 \pm 1.85^{\mathrm{a}} \\
9.53 \pm 0.70^{\mathrm{a}} \\
9.50 \pm 0.58^{\mathrm{a}}\end{array}$ \\
\hline
\end{tabular}

${ }^{\mathrm{a}-\mathrm{c}}$ Values with different superscripts indicate significant difference between cultures at each time point for each enzyme $(P<0.01)$.

${ }^{1}$ All values indicate averages of relative expression levels of each gene at different time points against those at $8 \mathrm{~h}$ of Bifidobacterium longum BB536 in fermented milk (mean \pm SD, triplicate assays). All expression values indicate relative score defined average score of fermented milk using B. longum BB536 at 8hr as 1.00 (mean $\pm \mathrm{SD}$, triplicate assays).

${ }^{2}$ Skim milk was fermented for $16 \mathrm{~h}$ until decreasing $\mathrm{pH}$ approximately 4.6 . Period of $8 \mathrm{~h}$ is an exponential phase at $\mathrm{pH}$ approximately 5.0 . 
al. (2004) reported that type strain of B. longum could almost survive in a $\mathrm{H}_{2} \mathrm{O}_{2}$ concentration of $2,000 \mathrm{ppm}$ $(58.82 \mu M)$. In the present study, it was found that the viability of $B$. longum BB536 was not affected in the presence of hydrogen peroxide at concentrations up to $100 \mu M$, a level higher than those detected in the media of coculture of B. longum BB536 with Lc. lactis ssp. lactis MCC866 (data not shown). Therefore, we suggest that the differences of $\mathrm{H}_{2} \mathrm{O}_{2}$ concentration observed in the present study would not affect the survival of bifidobacteria.

One of the main targets for reactive oxygen species is DNA. Presently, DNA degradation was evident in fermented milk containing B. longum BB536 in monoculture or coculture with Lc. lactis ssp. lactis MCC857, but not in those cocultivated with Lc. lactis ssp. lactis MCC866 after 21 d of storage. Rezaiki et al. (2004) reported the degradation of genomic DNA of Lc. lactis ssp. lactis after aeration for $48 \mathrm{~h}$. In the present study, the degradation of genomic DNA was observed after $21 \mathrm{~d}$ of storage and approximately 1 wk later after the DO was elevated to a near-saturating level in fermented milk containing B. longum BB536 in monoculture or coculture with Lc. lactis ssp. lactis MCC857. Degradation was not associated with cell lysis, as whole microorganisms were collected by centrifugation. Whether the degradation of genomic DNA was the cause or the consequence of the lost viability of bifidobacterial cells in the fermented milk is uncertain, because the partial loss of viability was observed 1 wk earlier than the detection of degradation of genomic DNA for each sample.

Both Lc. lactis and B. longum are devoid of catalase, a key enzyme for scavenging $\mathrm{H}_{2} \mathrm{O}_{2}$, and have to rely on enzymes such as NADH oxidase and NADH peroxidase to scavenge environmental oxygen. Indeed, NADH oxidase and NADH peroxidase function harmonically in preventing bacterial cells from oxidation; NADH oxidase functions in conversion of oxygen to $\mathrm{H}_{2} \mathrm{O}_{2}$, and $\mathrm{NADH}$ peroxidase is involved in scavenging $\mathrm{H}_{2} \mathrm{O}_{2}$ (Shimamura et al., 1992). Alkyl hydroperoxide reductase $(a h p C)$, which forms 2-component enzymes to convert oxygen to $\mathrm{H}_{2} \mathrm{O}$ via $\mathrm{H}_{2} \mathrm{O}_{2}$, was expressed at higher levels during storage in Lc. lactis ssp. lactis MCC 866 compared with Lc. lactis ssp. lactis MCC857. On the other hand, a significant difference was observed in the level of expression of ahpC by B. longum BB536 between each cultivating system after $14 \mathrm{~d}$ storage: monoculture $>$ coculture with Lc. lactis ssp. lactis MCC857 > coculture with Lc. lactis ssp. lactis MCC866. The different levels of $a h p C$ expression by $B$. longum BB536 and $L c$. lactis ssp. lactis may indicate that, from the need to scavenge $\mathrm{H}_{2} \mathrm{O}_{2}$, B. longum BB536 activates its own engines such as ahpC in monocultivating systems, while
BB536 does not activate them in the Lc. lactis spp. lactis cocultivating systems. However, further studies are needed to confirm the results as well as to evaluate the mechanisms. Taken together, these results suggest a key role of $a h p \mathrm{C}$ in maintaining low DO levels in fermented milk during refrigerated storage.

As shown in Figure 1, supplementation of catalase to $B$. longum BB536 monocultures did not affect the viability of $B$. longum BB536 or the concentration of DO, although the concentration of $\mathrm{H}_{2} \mathrm{O}_{2}$ was decreased during storage. These results indicated that scavenging of $\mathrm{O}_{2}$ by Lc. lactis ssp. lactis MCC866 principally contributed to the improved viability of $B$. longum BB536. We observed no expressional difference of the gene encoding $\mathrm{H}_{2} \mathrm{O}_{2}$-forming $\mathrm{NADH}$ oxidase between Lc. lactis ssp. lactis MCC866 and MCC857; however, some differences in activities of their proteins or of other $\mathrm{H}_{2} \mathrm{O}_{2}$-producing enzymes might occur.

Previous reports have indicated an influence of dissolved oxygen in yogurt on the viability of bifidobacteria (Talwalkar and Kailasapathy, 2003; Jayamanne and Adams, 2006). Attempts to provide a low concentration of DO environment by cocultivating with Streptococcus thermophilus STH450, a strain having a high oxygen uptake ability, have also been reported to enhance the survival of bifidobacteria in fermented milk (Teraguchi et al., 1987). These findings are similar to our findings; however, the advantage of our coculture system is that Lc. lactis can grow at low temperatures, which allows this system to be potentially activated even under refrigerated storage conditions.

Concerning iron metabolism, Herve-Jimenez et al. (2009) reported that, in a coculture system of $S$. thermophilus with $L b$. delbrueckii ssp. bulgaricus, the expression of genes potentially encoding iron transporters of $S$. thermophilus decreased, whereas that of ironchelating dpr (dps, DNA binding protein-starved cells, like the peroxide resistance gene) as well as that of the fur (ferric transport regulator protein, perR) regulator genes increased. The authors proposed that $S$. thermophilus sets up an adaptive response to $\mathrm{H}_{2} \mathrm{O}_{2}$ released from $L b$. bulgaricus by lowering the intracellular iron concentration in the coculture system.

In our study, as compared with Lc. lactis ssp. lactis $\mathrm{MCC} 866$, the expression of the gene encoding $\mathrm{Fe}^{2+}$ transport system in Lc. lactis ssp. lactis MCC857 when cocultivated with B. longum BB536 was markedly lower at $14 \mathrm{~d}$, whereas that of dpsA, which codes for the iron chelator non-heme iron-binding ferritin, was higher. Because $B$. longum BB536 produces $\mathrm{H}_{2} \mathrm{O}_{2}$ during its growth in milk (data not shown), we propose that an adaptive $\mathrm{H}_{2} \mathrm{O}_{2}$ response may occur in Lc. lactis ssp. lactis MCC857 in response to $\mathrm{H}_{2} \mathrm{O}_{2}$ generated in the cocultivating system. However, the gene expression 
pattern for Lc. lactis ssp. lactis MCC866 was different from that of Lc. lactis ssp. lactis MCC857 and was somewhat inconsistent with that found by HerveJimenez et al. (2009). The difference of mechanism to reduce $\mathrm{H}_{2} \mathrm{O}_{2}$ between Lc. lactis spp. lactis strains is not clear and needs further study. However, one possibility is that Lc. lactis ssp. lactis MCC866 has a different $\mathrm{H}_{2} \mathrm{O}_{2}$ response system because this strain has stronger activity of $\mathrm{H}_{2} \mathrm{O}_{2}$ scavengers such as alkyl hydroperoxide reductase. Otherwise, taking into account the facts that MCC866 seems to be more active in uptake of free iron and the expression of $d p s A$ progressively lessened during storage (Table 2), the intracellular concentration of free ferrous iron might be lower as a result of efficient biological utilization in the bacterial cells.

The extracellular free ferrous ion levels were lower in the fermented milk containing $B$. longum BB536 cocultivated with Lc. lactis ssp. lactis MCC866 compared with those of monoculture or coculture with Lc. lactis ssp. lactis MCC857. Ferrous ion plays an important role as a coenzyme of oxidoreductase in vivo. Furthermore, numerous studies have revealed the importance of free intracellular iron in exacerbating oxidative stress, by participating in the Fenton reaction (Storz and Imlay, 1999). The low concentration of free ferrous ion in coculture with Lc. lactis ssp. lactis MCC866 might consequently protect bifidobacterial cells from strong oxidants such as hydroxyl radical. Lactococcus lactis ssp. lactis has been reported to have respiratory-chain harboring genes coding for iron-binding proteins (Pedersen et al., 2008). We also observed that expression of genes coding respiratory-chain components such as cytochrome bd were significantly higher in Lc. lactis ssp. lactis MCC866 compared with MCC857 during refrigerated storage (Supplementary Table 2, available online: http://www.journalofdairyscience.org).

In conclusion, the data from Lc. lactis ssp. lactis MCC866 suggest that bifidobacterial cells are protected from oxygen damage from lowered DO levels in a coculture system. Several genes that participate in protecting cells from active oxygen species and that are expressed at higher levels by this strain during refrigerated storage are thought to be related to the improved survival of bifidobacteria in the cocultivated fermented milk. Other mechanisms may also contribute to the improved viability of bifidobacteria; an improved acid-tolerance of $B$. longum BB536 was observed after fermentation in coculture with Lc. lactis ssp. lactis MCC866 compared with B. longum BB536 monoculture (data not shown). Further studies are needed to reveal the mechanisms such as assessing the activities of enzymes that participated in protection from active oxygen species in the fermented milk.

\section{ACKNOWLEDGMENTS}

We express sincere thanks to N. Fujita (Takaya) and K. Fujisaki (Analytical Research Center, Morinaga Milk Industry Co. Ltd., Tokyo, Japan) for helpful technical assistance.

\section{REFERENCES}

Adhikari, K., A. Mustapha, I. U. Grün, and L. Fernando. 2000. Survival of microencapsulated bifidobacteria in set yogurt during refrigerated storage. J. Dairy Sci. 83:1946-1951.

Condon, S. 1987. Responses of lactic acid bacteria to oxygen. FEMS Microbiol. Rev. 46:269-280.

Doleyres, Y., I. Fliss, and C. Lacroix. 2004. Increased stress tolerance of Bifidobacterium longum and Lactococcus lactis produced during continuous mixed-strain immobilized-cell fermentation. J. Appl. Microbiol. 97:527-539.

Duwat, P., S. D. Ehrlich, and A. Gruss. 1995. The recA gene of Lactococcus lactis: Characterization and involvement in oxidative and thermal stress. Mol. Microbiol. 17:1121-1131.

Duwat, P., S. D. Ehrlich, and A. Gruss. 1999. Effects of metabolic flux on stress response pathways in Lactococcus lactis. Mol. Microbiol. $31: 845-858$.

FAO/WHO. 2002. Guidelines for the Evaluation of Probiotics in Food. Joint Working Group Report on Drafting Guidelines for the Evaluation of Probiotics in Food, London, Ontario, Canada. Food and Agriculture Organization of the United Nations and the World Health Organization.

Gilliland, S. E., S. S. Reilly, G. B. Kim, and H. S. Kim. 2002. Viability during storage of selected probiotic lactobacilli and bifidobacteria in a yogurt-like product. J. Food Sci. 67:3091-3095.

Herve-Jimenez, L., I. Guillouard, E. Guedon, S. Boudebbouze, P. Hols, V. Monnet, E. Maguin, and F. Rul. 2009. Post genomic analysis of Streptococcus thermophilus co-cultivated in milk with Lactobacillus delbrueckii ssp bulgaricus: Involvement of nitrogen purine and iron metabolism. Appl. Environ. Microbiol. 75:2062-2073.

Imlay, J. A., S. M. Chin, and S. Linn. 1988. Toxic DNA damage by hydrogen peroxide through the Fenton reaction in vivo and in vitro. Science 240:640-642.

Jayamanne, V. S., and M. R. Adams. 2006. Determination of survival, identity and stress resistance of probiotic bifidobacteria in bioyoghurts. Lett. Appl. Microbiol. 42:189-194.

Leahy, S. C., D. G. Higgins, G. F. Fitzgerald, and D. van Sinderen. 2005. Getting better with bifidobacteria. J. Appl. Microbiol 98:1303-1315.

Lee, H. M., and Y. Lee. 2008. A differential medium for lactic acidproducing bacteria in a mixed culture. Lett. Appl. Microbiol. 46:676-681.

Maragkoudakis, P. A., C. Miaris, P. Rojez, N. Manalis, F. Magkanari, G. Kalantzopoulos, and E. Tsakalidou. 2006. Production of traditional Greek yoghurt using Lactobacillus strains with probiotic potential as starter adjuncts. Int. Dairy J. 16:52-60.

Marty-Teysset, C., F. de la Torre, and J. Garel. 2000. Increased production of hydrogen peroxide by Lactobacillus delbrueckii ssp. bulgaricus upon aeration: Involvement of an NADH oxidase in oxidative stress. Appl. Environ. Microbiol. 66:262-267.

Miyoshi, A., T. Rochat, J. J. Gratadoux, Y. Le Loir, S. C. Oliveira, P. Langella, and V. Azevedo. 2003. Oxidative stress in Lactococcus lactis. Genet. Mol. Res. 2:348-359.

Mollet, B. 1999. Genetically improved starter strains: Opportunities for the dairy industry. Int. Dairy J. 9:11-15.

Ongol, M. P., Y. Sawatari, Y. Ebina, T. Sone, M. Tanaka, F. Tomita A. Yokota, and K. Asano. 2007. Yoghurt fermented by Lactobacillus delbrueckii ssp. bulgaricus $\mathrm{H}^{+}$-ATPase-defective mutants exhibits enhanced survival of Bifidobacterium breve during storage. Int. J. Food Microbiol. 116:358-366.

Pedersen, M. B., C. Garrigues, K. Tuphile, C. Brun, K. Vido, M. Bennedsen, H. Møllgaard, P. Gaudu, and A. Gruss. 2008. Impact 
of aeration and heme-activated respiration on Lactococcus lactis gene expression: Identification of a heme-responsive operon. $\mathrm{J}$ Bacteriol. 190:4903-4911.

Picard, C., J. Fioramonti, A. Francois, T. Robinson, F. Neant, and C. Matuchansky. 2005. Bifidobacteria as probiotic agents-Physiological effects and clinical benefits. Aliment. Pharmacol. Ther. $22: 495-512$.

Rezaïki, L., B. Cesselin, Y. Yamamoto, K. Vido, E. van West, P. Gaudu, and A. Gruss. 2004. Respiration metabolism reduces oxidative and acid stress to improve long-term survival of Lactococcus lactis. Mol. Microbiol. 53:1331-1342.

Samona, A., and R. K. Robinson. 1994. Effect of yogurt cultures on the survival of bifidobacteria in fermented milks. Int. J. Dairy Technol. 47:58-60.

Shah, N., and P. Jellen. 1990. Survival of lactic acid bacteria and their lactases under acidic conditions. J. Food Sci. 55:506-509.

Shimamura, S., F. Abe, N. Ishibashi, H. Miyakawa, T. Yaeshima, T. Araya, and M. Tomita. 1992. Relationship between oxygen sensitivity and oxygen metabolism of Bifidobacterium species. J. Dairy Sci. 75:3296-3306.

Storz, G., and J. A. Imlay. 1999. Oxidative stress. Curr. Opin. Microbiol. 2:188-194.
Talwalkar, A., and K. Kailasapathy. 2003. Metabolic and biochemical responses of probiotic bacteria to oxygen. J. Dairy Sci. 86:25372546 .

Teraguchi, S., and J. Ono., IKiyosawa, , and S. Okonogi. 1987. Oxygen uptake activity and aerobic metabolism of Streptococcus thermophilus STH450. J Dairy Sci. 70:514-523.

Turroni, F., D. van Sinderen, and M. Ventura. 2009. Bifidobacteria: From ecology to genomics. Front. Biosci. 14:4673-4684.

van de Guchte, M., S. D. Ehrlich, and E. Maguin. 2001. Production of growth-inhibiting factors by Lactobacillus delbrueckii. J. Appl. Microbiol. 91:147-153.

Van Niel, C. W., C. Feudtner, M. M. Garrison, and D. A. Christakis. 2002. Lactobacillus therapy for acute infectious diarrhea in children: A meta-analysis. Pediatrics 109:678-684.

Yamada, T., H. Tanaka, and K. Shimosaka. 2006. Technology trend of ICP-MS and its application. J Soc. Inorg. Mater. 13:64-70.

Yonezawa, S., J. Z. Xiao, T. Odamaki, T. Ishida, K. Miyaji, A. Yamada, T. Yaeshima, and K. Iwatsuki. 2010. Improved growth of bifidobacteria by co-cultivation with Lactococcus lactis ssp. lactis. J. Dairy Sci. 93:1815-1823. 